Jurnal Konstruksi Hukum | ISSN: 2746-5055

Vol. 2, No. 2, Mei 2021, Hal. 271-276| Tersedia online di

https://www.ejournal.warmadewa.ac.id/index.php/jukonhum

DOI: https://doi.org/10.22225/jkh.2.2.3219.271-276

\title{
TINJAUAN YURIDIS TERHADAP SELEBGRAM YANG MELAKUKAN ENDORSE/PROMOSI BARANG ILEGAL PADA PRODUK OBAT-KOSMETIK
}

\author{
Kadek Agus Adi Mego, I Nyoman Putu Budiartha, Ni Made Puspasutari Ujianti \\ Fakultas Hukum Universitas Warmadewa, Denpasar-Bali, Indonesia \\ dekgo@gmail.com, budiarthaputu59@gmail.com, puspasutariujianti@gmail.com
}

\begin{abstract}
Abstrak
Selebgram adalah selebriti yang eksis pada akun media sosial lnstagram yang menjadi publik figur dalam media sosial Instagram. Viralnya sosok selebgram pada instagram di jadikan peluang bagi pelaku usaha untuk mengendorse atau mempromosikan produk kosmetik melalui akun Instagram milik selebgram tersebut. Kegiatan tersebut memunculkan dampak negatif, yaitu produk yang dipromosikan adalah barang ilegal yang tidak mempunyai izin dari lembaga terkait dan hal itu dapat menyebabkan kerugian bagi konsumen. Penelitian ini bertujuan untuk mengetahui peraturan dan sanksi hukum terhadap selebgram yang melakukan promosi terhadap barang illegal produk obat kosmetik. Penelitian ini menggunakan tipe penelitian hukum normatif. Adapun pendekatan digunakan yaitu pendekatan Perundang-undangan yang berkaitan dengan permasalahan yang diteliti, sumber data yang digunakan adalah bahan hukum primer dan sekunder, bahan hukum primer meliputi Undang-Undang No 8 Tahun 1999, Undang-Undang No 19 Tahun 2016 dan kitab Undang-Undang Hukum Perdata menjadi dasar hukum untuk mengetahui pengaturan hukum dan sanksi hukum terhadap selebgram yang mengendorse atau mempromosikan barang ilegal. Hasil penelitian ini menunjukan bahwa pengaturan sanski sesuai Undang-Undang No 8 Tahun 1999 Pasal 9 ayat 1 yang menyatakan di dalamnya dalam menjalankan promosi dilarang menawarkan, mempromosikan, mengiklankan suatu barang atau jasa secara tidak benar, dan atau seolah-olah barang tersebut telah mendapatkan persetujuan artinya produk tersebut telah mendapatkan izin dari lembaga, dan terkait penjatuhan sanksi hukum terhadap selebgram berbeda dengan pelaku usaha yang menjadi produsen dari produk tersebut.
\end{abstract}

Kata Kunci: Barang Ilegal, Selebgram, Promosi, Produk Kosmetik

\begin{abstract}
Selebgrams are celebrities who exist on lnstagram social media accounts and become public figures on lnstagram social media. The viral figure of celebrities on Instagram is used as an opportunity for business people to endorse/promote cosmetic products through Celegram's Instagram account. However, these activities have a negative impact, namely, the products being promoted are illegal goods that do not have permission from the relevant institutions and this can cause harm to consumers. In terms of writing this research the writer discusses two legal issues, namely the legal arrangement for celebrities who endorse/promote cosmetic medicinal products and legal sanctions against celebrities who endorse/promote illegal goods in cosmetic medicinal products. This research aims to determine the regulations and legal sanctions against celebrities who promote illegal cosmetic medicinal products. This research uses the type of normative legal research, Law No. 8 of 1999, Law No. 19 of 2016, and the Civil Code as a legal basis to determine legal arrangements and legal sanctions against celebrities who endorse/promote illegal goods. The problem approach used is the approach by analyzing legislation related to the problem. The results of this study indicate that the imposition of legal sanctions on celebrities is different from business actors who are producers of these products.
\end{abstract}

Keywords: Celebgram, Promotion,Illegal Goods, Cosmetic Products

\section{PENDAHULUAN}

Pada era globalisasi ini, penggunaan internet semakin berkembang dari hari ke hari. akibat perkembangan teknologi internet, banyak bermunculan media sosial, sehingga sosial media seolah membuat orang ketagihan bermain media sosial. Media sosial juga sudah mulai menggantikan peran media elektronik dan media massa konvensional, karena masyarakat beranggapan bahwa media sosial sangat cepat dalam menyebarkan berita atau informasi. Media sosial menyediakan dunia baru bagi masyarakat, dan media sosial digunakan sebagai dunia bisnis masyarakat. Dalam hal ini dunia bisnis adalah bisnis online. Promosi melalui social media dinilai efektif karena konsumen akan dengan cepat mengenali produk atau jasa (Fangestu, 2019). 
Munculnya sosial media lnstagram menyebabkan munculkan selebgram, yang dalam hal ini selebgram adalah seorang selebriti atau publik figure dalam media sosial instagram, dengan banyaknya pengikut dalam akun sosial media lnstagram milik selebgram tersebut dijadikan peluang bisnis oleh pelaku usaha unruk mempromosikan produk obat kosmetik pada akun selebgram tersebut. Cara kerja endorsement sangatlah mudah, pelaku usaha mengirimkan produk dagangannya kepada endorser kemudian endorser membagikan foto kreatif dari produk tersebut dan dibagikan pada akun media sosial endorser (Pusnawan, 2020). Tujuan dari endorsement tersebut adalah agar para pengikut dalam akun Instagram selebgram tersebut mau mengik:uti produk kosmetik yang dipakai dan di promosikan oleh selebgram tersebut. Pada sebelum nya pelaku usaha dapat memasang iklan baik melalui media elektronik, (televisi, radio, internet), maupun media elektronik (majalah, surat kabar, billboard) (Harianto, 2010:10), Tapi di era sekarang ini, efek menggunakan benda-benda ini untuk promosi tidak baik, dan orang tidak peduli. Seiring dengan berkembangannya teknologi serta informasi serta laju pertumbuhan internet membuat internet menjadi salah satu media yang efektif bagi pelaku usaha untuk memperkenalkan serta menjual barang atau jasa ke calon konsumen dari seluruh dunia yang kita kenal sebagai transaksi tanpa kertas (paperless) dan tidak bertemu secara langsung (face to face) (Barkatullah, 2009:4).

Kegiatan endorse/promosi yang dilakukan oleh para selebgram pada akun media sosial Instagram memunculkan dampak negatif yaitu barang yang dipromosikan merupakan barang ilegal dalam hal ini tanpa seizin instansi terkait. Tentunya hal ini dapat merugikan konsumen, ditambah lagi hajatan promosi I pengakuan kosmetik menandakan bahwa kosmetik tersebut aman, terpercaya dan bergaransi.

Meninjau Pasal 28F Undang-Undang Dasar Negara Republik Indonesia Tahun 1945, terlihat jelas bahwa setiap orang membutuhkan informasi yang jelas dari semua saluran yang ada. Artinya, konsumen memiliki hak untuk mendapatkan informasi sejelas mungkin tentang produk yang disetujui oleh rencana, dan berhak atas keadilan atas tindakan ilegal yang dilakukan oleh pelaku usaha dan selebgram . Jika ini terjadi, maka sudah ada dasar hukumnya yaitu Undang-Undang Perlindungan Konsumen Nomor 8 Tahun 1999.

Perlindungan konsumen, dalam rangka mewujudkan hak atas informasi barang I produk yang diimpor secara ilegal yang diendorse oleh selebgram terdapat pada Pasal 4 huruf C Undang-Undang No 8 Tahun 1999 tentang Perlindungan Konsumen, dalam pasal tersebut konsumen berhak mendapatkan informasi yang jelas jujur dan benar mengenai kondisi produk kosmetik tersebut. Berdasarkan Pasal 2 ayat (1) Peraturan Kepala Sadan Pengawas Obat Dan Makanan Republik Indonesia Nomor 18 Tahun 2016 tentang Pedoman Teknis Pengawasan lklan Kosmetika, hal ini berarti kosmetik baru boleh beredar dan diiklankan apabila telah terdaftar dan mendapatkan izin edar berupa notifikasi dari Badan Pengawas Obat dan Makanan (selanjutnya disebut BPOM).

Dalarn rangka mempromosikan kosmetik ilegal di media sosial lnstagrarn, para seleb dalarn hal ini memberikan informasi yang tidak jujur dan tidak benar. Hal tersebut melanggar hukum yang berlaku khususnya di Indonesia. Selayaknya selebgram tersebut mendapatkan sanksi pidana karena telah menginformasikan berita bohong kepada konsumen. Terkait dengan informasi menyesatkan yang diatur dalam Pasal 45A Undang-Undang 19A Tahun 2016, perbuatan menyebarkan informasi yang menyesatkan adalah tindakan dengan sengaja menyebarkan berita palsu dan menyesatkan tanpa hak untuk merugikan konsumen dalam transaksi elektronik, khususnya di dunia online, tujuan penyebaran informasi yang menyesatkan adalah untuk meyakinkan pembaca atau pemirsa informasi tersebut dan terpengaruh olehnya. Hal ini tentu saja merugikan konsumen. Untuk itu hukum sangat diperlukan agar tidak terjadinya hal-hal yang tidak diinginkan. Menurut Radbruch tujuan hukum yaitu:

1) Keadilan (Bahasa Belanda gerechtstigheid, Bahasa Inggris Justice) berkenaan dengan prinsip penyelesaian sengketa bahwa terdapat kasus yang sama harus diperlukan secara sama pula (asas similiasimilibus).

2) Kepastian hukum (Bahasa Belanda techtstekerheid, Bahasa lnggris Legal certainty) dalam arti hukum ditegakkan secara pasti, konsekuen, Yan Apeldom berpendapat bahwa kepastian hukum memiliki dua makna yakni (i) pihak-pihak pencari keadilan (justiabellen) dapat mengetahui apa hukum yang diperlakukan dalarn perkara yang dihadapinya (ii) keamanan hukum artinya para pihak yang berperkara mendapat perlindungan untuk tidak diperlakukan sewenang-wenang oleh hakim 
3) Kemanfaatan atau kegunaan (Bahasa Belanda doelmatigheid, Bahasa lnggris expediency) dalam arti, hukum memiliki nilai penting baik untuk individu maupun untuk masyarakat dan untuk karya manusia di bidang kebudayaan, ilmu, dan teknologi (Atmadja \& Budiartha, 2019 43-44).

Dari uraian permasalahan di atas, penelitian ini dilkaukan dengan tujuan Penelitian ini bertujuan untuk mengetahui peraturan dan sanksi hukum terhadap selebgram yang melakukan promosi terhadap barang illegal produk obat kosmetik

\section{METODE PENELITIAN}

Penelitian ini merupakan penelitian hukum normatif yang didasarkan pada data hukum primer. Penelitian ini menggunakan pendekatan perundang-undangan (The Statue Approach) yaitu review terhadap peraturan perundang-undangan terkait dengan masalah hukum yang sedang diteliti (Marzuki, 2005) dan pendekatan konseptual (conceptual approach) yaitu pendekatan yang beranjak dari pandangan-pandangan dan doktrin-doktrin yang berkembang di dalam ilmu hukum (Susanti \& Effendi,2014). Oleh karena itu, penelitian ini menitikberatkan pada masalah yang dikaji sesuai dengan ruang lingkup yang telah ditentukan (Gie, 1982). Mengenai sumber bahan hukum yang digunakan terbagi atas Bahan Hukum primer yaitu suatu peraturan perundang-undangan yang memiliki kaitan langsung maupun tidak langsung dari kasus selebgram yang melakukan endorse atau promosi barang ilegal pada produk obat kosmetik. Bahan hukum sekunder yaitu semua publikasi tentang hukum yang merupakan dokumen yang tidak resmi. Publikasi tersebut terdiri dari buku-buku teks yang membicarakan suatu atau beberapa permasalahan hukum. Selain itu bahan hukum sekunder juga memberikan penjelasan berkenaan dengan bahan hukum primer yaitu seperti jurnal-jurnal hukum. Ketiga yaitu komentar-komentar atas putusan hakim. Publikasi tersebut merupakan petunjuk atau penjelasan mengenai bahan hukum primer atau bahan hukum sekunder yang berasal dari, ensiklopedia, jumal, surat kabar dan sebagainya (Soekanto, 2003:36-37). Teknik pengumpulan bahan hukum yang digunakan dalam penelitian ini adalah teknik studi kepustakaan (library research) yaitu dengan membaca, mencatat, mengutip, meringkas, dan mengulas informasi data-data dari peraturan perundang-undangan maupun literarur-literarur yang berkaitan dengan permasalahan. Dengan meninjau peraruran perundang-undangan dan mencari bahan melalui buku-buku yang berkaitan dengan tinjaun yuridis terhadap selebram yang melakukan endorselpromosi barang ilegal.

\section{PEMBAHASAN}

\section{Pengaturan Hukum terhadap Selebgram yang Melakukan Endorse Promosi pada Produk Obat Kosmetik}

Berdasarkan Undang-Undang Nomor 8 Tahun 1999 tentang Perlindungan Konsumen, pada Pasal 1 ayat (6) menjelaskan bahwa kegiatan promosi adalah kegiatan yang memberi pengenalan atau penyebaran inforrnasi suatu barang untuk menarik minat dari konsumen. Dalam melakukan kegiatan promosi produk, pelaku usaha dalam hal melakukan kerja sama dengan selebgram untuk mempromosikan produk kosmetik pada akun sosial media Instagram milik selebgram tersebut.

Selain itu dalam menjalankan kegiatan promosi memiliki kewajiban yaitu tertera dalam Undang-undang No 8 Tahun 1999 tentang Perlindungan Konsumen, pada Pasal 7 huruf 8 yang menjelaskan bahwa dalam mempromosikan harus memberikan informasi yang benar, jelas dan jujur mengenai kondisi dan jaminan barang atau jasa serta memberi penjelasan penggunaan, perbaikan dan pemeliharaan, hal ini bertujuan untuk memberikan rasa aman kepada konsumen dan menciptakan penjualan produk yang transparan dan kualitasnya terjamin untuk diperdagangkan. Adanya informasi yang jelas dan jujur, dengan itu masyarakat sebagai konsumen menjadi percaya akan produk kosmetik yang dipromosikan oleh selebgram tersebut.

Apabila konsumen sudah percaya akan produk kosmetik yang dipromosikan tentu saja akan dibeli dan penjualan produk kosmetik pun mendapatkan keuntungan. Pentingnya penyampaian informasi yang benar terhadap konsumen mengenai suatu produk, agar konsumen tidak salah terhadap gambaran mengenai suatu produk tertentu. Ketiadaan informasi yang tidak memadai dari pelaku usaha merupakan cacat produk (cacat informasi), yang akan sangat merugikan konsumen. Mengenai kegiatan promosi tentu saja harus dapat memenuhi salah satu hak konsumen yaitu terdapat pada Pasal 4 huruf C Undang-Undang No 8 Tahun 1999 tentang Perlindungan Konsumen yang menjelaskan bahwa konsumen berhak atas informasi yang benar, jelas, dan jujur mengenai kondisi dan jaminan barang dan/atau jasa Pada Peraturan Menteri Perdagangan nomor 70 tahun 2019 tentang distribusi 
barang secara langsung sudah dijelaskan pada Pasal 21 huruf a yang menyatakan bahwa perusahaan dilarang menawarkan, mempromosikan, mengiklankan Barang secara tidak benar, berbeda, atau bertentangan dengan keadaan yang sebenarnya lni berarti setiap pelaku usaha atau selebgram wajib menawarkan, mempromosikan, dan mengiklankan barang yang dijualnya dengan jujur dan benar, tidak adanya pemalsuan atau dari informasi yang berikan, sehingga masyarakat sebagai konsumen memiliki rasa percaya terhadap produk yang dibelinya.

\section{Sanksi Hukum terhadap selebgram yang Melakukan Endorse Promosi Barang Ilegal pada Produk Obat Kosmetik}

Perkembangan teknologi telah menciptakan dunia baru yang dikenal dinamakan cyberspace yang juga dikenal dengan sebutan internet. Cyberspace adalah ruang maya, terhubungnya komputer-komputer dengan saluran penyedia jasa internet yang dapat diakses kapan saja, tidak mengenal batas ruang dan wakru (Sutarman, 2007:4).

Perkembangan teknologi tidak hanya membuka peluang munculnya kejahatan-kejahatan baru yang selama ini dianggap tidak mungkin terjadi atau tidak terpikirkan akan terjadi, tetapi juga memberikan kemudahan dalam melakukan kejahatan-kejahatan yang telah ada atau telah sering terjadi. Oleh karena itu Undang-Undang lnformasi. Transaksi, Elektronik ITE sangat dibutuh untuk membatasi halhal yang menyalahi aturan dalam perkembangan teknologi komunikasi dan informasi.

Mempromosikan produk kosmetik yang yang tidak mempunyai izin edar artinya memberikan informasi yang tidak benar kepada masyarakat sebagai konsurnen dengan menjelaskan bahwa produk yang dipromosikan asli dan memiliki izin dari lembaga terkait. Memberikan informasi yang tidak benar artinya selebgram tersebut memberikan berita bohong pada sosial media. Berdasarkan UndangUndang Nomor 19 Tahun 2016 perubahan atas Undang-Undang Nomor 11 Tahun 2008 tentang lnformasi dan Transaksi Elektronik pada Pasal 45A ayat (1) menjelaskan bahwa setiap orang yang artinya dalam hal ini adalah selebgram melakukan promosi dengan sengaja dan tanpa hak menyebarkan berita bohong dan menyesatkan yang mengakibatkan kerugian konsumen, jika hal tersebut terjadi maka sanksi hukum pidana yang didapat adalah penjara paling lama 6 (enam) tahun atau denda paling banyak Rp 1.000.000.000,00 (satu miliar rupiah). Sehingga selebgram dalam mempromosikan produk kosmetik ilegal pada media sosial dapat dikategorikan telah menyebarkan informasi yang tidak benar mengenai produk kosmetik ilegal tersebut. Dimana produk kosmetik tersebut tidak memiliki izin edar dan tidak memenuhi persyaratan untuk diedarkan yang mengakibatkan tidak amannya produk kosmetik tersebut untuk dikonsumsi maupun digunakan oleh konsumen. Seharusnya selebgram dalam mempromosikan produk kosmetik rnemberikan informasi yang jujur dan benar mengenai produk tersebut.

Membahas sanksi terhadap selebgram yang menyebarkan informasi yang tidak benar harus memenuhi unsur yang terdapat pada Pasal 45A ayat (1) Undang- Undang Nomor 19 Tahun 2016 perubahan atas Undang-Undang Nomor 11 Tahun 2008 tentang Informasi dan Transaksi Elektronik sebagai berikut: kesalahan dengan sengaja melawan hukum tanpa hak perbuatan menyebarkan objek berita bohong dan menyesatkan akibat konstitutif mengakibatkan kerugian konsumen dalam transaksi elektronik selebgram dapat dikenai sanksi hukum pidana penyebaran informasi tidak benar apabila telah memenuhi unsur-unsur seperti diatas, sebab mempromosikan produk kosmetik dalarn sosial media selebgram haruslah memberikan informasi sejelas jelasnya tentang keaslian produk, izin produk. Apabila selebgram tersebut tidak memiliki itikad baik dalam mempromosikan produk kosmetik pada social media tentu saja konsumen merasa dibohongi akibat dari perbuatannya. Banyak selebgram yang tidak memperdulikan tentang keamanan dan bahaya dari mempromosikan produk kosmetik ilegal, selebgram yang mempromosikan produk kosmetik hanya memikirkan keuntungan dari mempromosikan produk kosmetik pada sosial media.

Dilihat dari hukum perdata konsumen yang mengalami kerugian akibat dari penggunaan produk kosmetik ilegal, konsumen dapat menggugat selebgram yang mempromosikan produk kosmetik ilegal tersebut melalui jalur perdata dengan mengajukan gugatan perbuatan melawan hukum. Pada Pas al 1365 Kitab Undang-Undang Hukum Perdata (KUHPerdata), perbuatan melawan hukum yang dilakukan oleh selebgram haruslah dipertanggungjawabkan sesuai dengan peraturan perundang-undangan yang ada. Berdasarkan Pasal 1365 Kitab Undang-Undang Hukum Perdata (KUHPer) jika selebgram terbukti melakukan perbuatan melawan hukum harus memenuhi unsurunsur yaitu menimbulkan kerugian bagi orang lain, perbuatan atau orang yang bersalah, mengganti 
rugi. Mengenai perbuatan yang dilakukan selebgram dapat dikatakan kurang hati-hati atau lalai dalam mempromosikan produk kosmetik pada sosial media miliknya, sesuai Pasal 1366 Kitab UndangUndang Hukum Perdata (KUHPerdata) mengatur mengenai pertanggungjawaban orang yang karena kurang hati-hati atau kelalaian menyebabkan kerugian bagi orang lain. Perbuatan selebgram tersebut menyebabkan kerugian terhadap konsumen yang percaya dengan postingan promosi yang dilakukan oleh selebgram pada akun media sosialnya yang ternyata produk kosmetik tersebut tidak memiliki izin.

\section{SIMPULAN DAN SARAN \\ 1. Simpulan}

Dari Pembahasan dan analisis data dapat disimpulkan bahwa Pengaturan hukum tentang selebgram yang melakukan promosi produk obat kosmetik diatur pada Undangan-Undang No 8 Tahun 1999 Pasal 9 ayat (1), yang menyatakan di dalamnya dalam menjalankan promosi dilarang menawarkan, mempromosikan, mengiklankan suatu barang atau jasa secara tidak benar, atau seolah-olah barang tersebut telah rnendapatkan persetujuan artinya produk tersebut telah mendapatkan izin dari lembaga terkait. dalam Pasal tersebut juga dijelaskan bahwa dalam mempromosikan produk kosmetik dilarang memberikan informasi yang tidak sesuai dengan kondisi barang, yang artinya dalarn mernpromosikan harus memberikan informasi yang jujur dan jelas kepada konsumen, selanjutnya sanksi hukum pidana terhadap selebgram yang melakukan endorse atau promosi produk kosmetik ilegal diatur dalam Undang-Undang No 19 tahun 2016 pada Pasal 45A ayat (1), dalam Pasal tersebut dijelaskan bahwa setiap orang dengan sengaja dan tanpa hak rnenyebarkan informasi palsu atau bohong rnendapatkan dipidana paling lama 6 tahun penjara dan denda paling banyak Rp. 1.000.000.000,00 (satu miliar rupiah). Apabila ada konsumen yang merasa dirugikan akibat promosi yang dilakukan oleh selebgram dapat menggugat secara perdata dijelaskan pada Pasal 1365 KUH Perdata dan diperkuat pada Pasal 1366 KUHPerdata, pada Pasal tersebut dijelaskan bahwa setiap orang yang menyebabkan kerugian bagi orang lain karena kesalahannya maka wajib untuk mengganti rugi kepada orang tersebut.

\section{Saran}

Dari hasil penelitian di atas, adapun saran yang diberikan yaitu diharapkan kepada pemerintah dalam hal ini dengan semakin majunya perkembangan teknologi dalam pengaturan hukum terhadap selebgram dibuatkan Undang-Undang yang jelas dan tegas. Pada Undang-Undang No. 8 Tahun 1999 tentang perlindungan konsumen, hanya terdapat pelaku usaha yang disebutkan, sedangkan dengan perkembangan dunia promosi semakin berkembang sangat diburuhkan Undang-Undang yang mengarur kegiatan promosi yang lebih luas, selanjutnya diharapkan pemerintah dalam membuat Rancangan Undang-Undang yang mengatur tentang selebgram yang mempromosikan suatu produk, sanksi hukum yang diterima oleh selebgram yang mempromosikan sebuah produk yang ilegal harus tegas dan tidak pandang bulu, mengingat promosi di zaman sekarang sangat gencar terjadi di dunia usaha, sudah seharusnya sudah ada sanksi hukum yang tegas agar tidak adanya konsurnen yang merasa dirugikan dari kegiatan promosi tersebut.

\section{DAFTAR PUSTAKA}

Barkatullah, A. H. (2009). Perlindungan Hukum Bagi Konsumen Dalam Transaksi E. Commerce Lintas Negara di Indonesia. FH UII Press, Yogyakarta.

Susanti, Dyah, O., \& Efendi, A. (2014). Penelitian Hukum (Legal Research). Sinar Grafika, Jakarta.

Harianto, D. (2010). Perlindungan Hukum bagi Konsumen terhadap lklan yang Menyesatkan. Ghalia Indonesia, Jakarta.

Atmadja, I. D. G., \& Budiartha, I. N. P. (2019). Sistematika Filsafat Hukum Perspektif Persoalan-persoalan Pokok. Setara Press, Malang.

Fangestu, M. A. (2019). Tinjauan Yuridis Peran Badan Pengawas Obat dan Makanan dalam Mengawasi Peredaran Produk Kosmetik Tanpa Izin yang Dipasarkan Secara Online dan Pertanggung Jawaban Pidana Beauty Influencer dan Pelaku Usaha dalam Hal Terjadinya Promosi Produk yang Mengandung. Fakultas Hukum. Universitas Kristen.

Gie, T. L. (1982). Ilmu Politik: Suatu Pembahasan Tentang Pengertian, Kedudukan Lingkup Metodologi. Gadjah Mada University Press.

Marzuki, P. M. (2005). Penelitian Hukum. Jakarta: Kencana Pranada Media Group. 
Pusnawan, I. M. L. (2020). Sanksi Hukum Terhadap Endorser yang Mempromosikan Produk Kosmetik Ilegal. Journal IJCCS, Vol. 8(7).

Soekanto, S. (2003). Penelitian Hukum Normatif Suatu Tinjauan Singkat. Rajawali Pers, Jakarta.

Sutarman. (2007). Cyber Crime Modus Operandi dan Penanggulangannya. Laksbang Pressindo, Yogyakarta. 